\title{
TERRITORIAL SYSTEM OF ECOLOGICAL STABILITY AS A PART OF LAND CONSOLIDATIONS (CADASTRAL TERRITORY OF GALANTA - HODY, SLOVAK REPUBLIC)
}

\author{
ERIKA KOČICKÁ ${ }^{1}$ ANDREA DIVIAKOVÁ ${ }^{1}$, DUŠAN KOČICKÝ ${ }^{2}$ ELIŠKA BELAŇOVÁ ${ }^{1}$
}

${ }^{1}$ UNESCO-Chair on Sustainable Development and Ecological Awareness, Faculty of Ecology and Environmental Sciences, Technical University in Zvolen, T. G. Masaryka 24, 96053 Zvolen, Slovak Republic; e-mail:kocicka@ tuzvo.sk, diviakova@tuzvo.sk, belanova@tuzvo.sk

${ }^{2}$ Esprit, s.r.o., Pletiarska 1, 96900 Banská Štiavnica, Slovak Republic; e-mail:kocicky@esprit-bs.sk

\begin{abstract}
Kočická E., Diviaková A., Kočický D., Belaňová E.: Territorial system of ecological stability as a part of land consolidations (cadastral territory of Galanta - Hody, Slovak Republic). Ekológia (Bratislava), Vol. 37, No. 2, p. 164-182, 2018.

A major worldwide problem, especially from the perspective of preserving biodiversity and ecological stability (ES) of the landscape, is the significant gradual degradation and loss of habitats. In the context of ever-changing global conditions, the preservation of healthy ecosystems and their valuable services as well as the interconnection of patches of existing habitats should be encouraged. In Slovakia, conception of the Territorial System of Ecological Stability (TSES) was developed. Biodiversity conservation can be created by means of an integrated approach to management of the landscape and careful spatial planning respecting TSES. Land Consolidation (LC) projects, of which TSES constitutes a key part, are amongst the real planning and implementation tools in the Slovak Republic. Thus, TSES represents a real tool for implementation of landscape changes in order to strengthen ES and biodiversity of the landscape with regard to the current European trends in biodiversity policy. This article describes a Local Territorial System of Ecological Stability (LTSES) project developed as a part of LCs in the cadastral territory of Hody (Galanta, Slovak Republic). The aim was to create a functional proposal of LTSES with all basic types of proposals to strengthen biodiversity and ES of model territory - proposal for establishing new eco-stabilising elements - groups and strips of non-forest woody vegetation (NFWV), proposal for ecologically optimal land use, proposal for eco-stabilising measures in forest ecosystems and proposal for hydro-ecological measures.
\end{abstract}

Key words: biodiversity, landscape-ecological evaluation, proposals, non-forest land, local level.

\section{Introduction and theoretical and methodological base}

The EU Biodiversity Strategy to 2020 (EC, 2011) entitled 'Our life insurance, our natural capital' states the commitment of the commission to create a strategy preservation of biodiversity. Six general targets are defined in the strategy. Target No. 2 states that by 2020, it is necessary to ensure that ecosystems and their services have been preserved and strengthened. Principles are also defined in 'The Revised National Strategy for the Protection of Biodiversity to 2020' (MoE SR, 2013). 
Investments in biodiversity enhancing are considered an important step towards the protection of 'natural capital'. Natural capital represents natural resources that provide valuable goods and services. The services of natural capital are referred to as ecosystem services. Protection and enhancement of natural capital are considered the elements leading to longterm sustainability.

In Slovakia, to preserve the biodiversity of the landscape, to restore natural landscape connectivity features and to maintain or enhance the ES of the territory, conception of the Territorial Systems of Ecological Stability (TSES) was created. At the same time, various studies that aimed at role, evaluation and planning of ES and biodiversity, especially the agricultural landscape, have been developed (e.g. Ružička et al., 1982; Brandt, 1985; Selman, 1993).

The TSES plan has been most widely elaborated in the Czech Republic. By the Czech school, the whole-territory approach to maintain the stabilisation of the landscape was proposed (Buček, Lacina, 1979; Buček et al., 1986; Míchal, 1992; Buček, Lacina, 1993; Buček et al., 1996).

In Slovakia, TSES was built based on the Czech principles together with the Institute of Landscape Ecology and other institutions (Jurko, 1986; Miklós, 1986; Miklós et al., 1986). The plan in the Slovak Republic follows up a whole range of international initiatives, for example, NATURA 2000 (European Network of Specially Protected Sites), substantially contributing to the biodiversity maintenance according to the ideas of the Convention on Biological Diversity (National Biodiversity Strategy of Slovakia, including its revisions; MoE SR, 1997, 2013), the Pan-European Biological and Landscape Diversity Strategy (ECNC, 1996), the European Landscape Convention (CE, 2000), AGENDA 21 (MoE SR, 1996) and so on.

TSES conception in Slovakia was built based on the plan of NECONET. The NECONET was based on the concept of the European Ecological Network (EECONET) and drew on the principles of the Dutch National Ecological Network. In foreign studies, the widely used term is 'ecological networks' (Mander et al., 1988; Cook, Van Lier, 1994; Brandt, 1995; Jongman, 1995; Kavaliauskas, 1995; Mander et al., 1995; Kubeš, 1996; Bennett, 1998; Bouwma, Jongman, 1998). Current trends and research confirm the relevance of the theoretical basis for the concept of ecological networks in the landscape (Mackovčin, 2000; Sepp, Kaasik, 2002; Wrbka et al., 2005; Bennett, Mulongoy, 2006; Opdam et al., 2006; Pascual, Dunne, 2006; Boitani et al., 2007; Bonnin, 2007; Ignatieva et al., 2011; Jongman et al., 2011; Buček, 2013; Schilleci et al., 2017).

The establishment of ecological networks has been proposed as a way to counteract the increasing fragmentation of natural ecosystems and as a necessary complement to the network of protected areas (Forman, 1983; Forman, Baundry, 1984; Agger, Brandt, 1988; Hobbs et al., 1990; Hargis et al., 1999).

From the theoretical and methodological point of view, TSES is a modern plan and tool for conservation and organisation of territory based on landscape-ecological approach (Naveh, Liebermann, 1994; Jongman, Kristiansen, 1998; Jongman, Pungetti, 2004; Tardy, Végh, 2006). The strategic principles of the TSES include diversity of conditions and forms of life - geoecodiversity, elimination of spatial isolation of geosystems, broad-based stabilisation of the territory, protection of natural resources, improvement of landscape ap- 
pearance and the overall quality of the environment (Miklós, 1996). The starting point of the protection strategy of diversity of conditions and life forms is the identification of the geoecosystems that need to be preserved (Bastian, Schreiber, 1994; Bunce et al., 1996; Jongman, Bunce, 2000; Miklós et al., 2006). The critical aspect of the geosystem approach to the landscape for its application in practical activities - and in the process of designing of TSES - is the character of the primary, secondary and tertiary landscape structures and their functions for the spatial planning process (Drdoš et al., 1995; Miklós, Izakovičová, 1997; Renetzeder et al., 2010).

The TSES plan adopted by Resolution of the Government of the Slovak Republic 394/1991 paved the way for the incorporation of the TSES into environmental policy and planning. Several methodological guidelines were produced as part of the development of TSES in Slovakia (SCE, 1992; MoE SR, 1993; Jančura et al., 1994; Izakovičová et al., 2000; Hrnčiarová et al., 2000; SEA, 2009). TSES also became a part of the greening of landscape of Slovakia (Miklós et al., 1990). The process of creating documentation of nature and landscape conservation (including TSES documentation) can be conducted in Slovakia only by people with the required professional qualifications.

The TSES is a binding regulation of various plans and projects as well as decision-making processes on all hierarchical levels (national, regional, local). The TSES produced with the precision of a local level, the Local Territorial System of Ecological Stability (LTSES), represents the most significant incorporation of landscape ecology principles to real environmental policy, spatial planning practice and the promotion and conservation of biodiversity.

The TSES constitutes the central idea of the current wording of Act 543/2002 Coll. on Nature and Landscape Protection as amended (Act on the Protection of Nature). In the Act, $\$ 2$ defines TSES as an integrated structure of interconnected ecosystems, their components and features, which ensures diversity of conditions and life forms in the landscape, whereby the base of the system consists of bio-centres, bio-corridors and interactive elements of supra-regional, regional or local importance (known as the elements of the TSES skeleton). The Act on Nature and Landscape Protection ( $\$ 3$ Art. 3) stipulates that establishing and preserving the TSES is a public interest. The space (landscape) in which the TSES is implemented, in geosystem terms, understood as a geosystem - 'landscape is a complex system of space, location, geo-relief and other mutually, functionally interconnected, material, natural elements and elements modified and created by man, in particular the geological base and soil creating substratum, water bodies, soil, flora and fauna, artificial objects and the elements of utilisation of territory, as well as their connections determined by socio-economic phenomena in the landscape; the landscape is the living space of man and other living organisms' (Act 50/1976 Coll. as amended by Act 237/2000 Coll., $\$ 139$ - Building Act).

As defined by $\$ 9$ Art. 9 of the Act 330/1991 Coll. on Ground Arrangements, Land Ownership, Land Offices, Land Fund and Land Associations (Act on Land Consolidations [LCs]), LTSES is a compulsory landscape-ecological document for general principles of spatial arrangement of the territory (GPFAT). The proposal of TSES skeleton and proposal of anti-erosion measures are ecological optimal variants of spatial arrangement and functional land use. The proposal of GPFAT is a rational variant of spatial arrangement and functional 
land use. GPFAT proposal is specified based on the more detailed knowledge of designers and comments and requests from participants of LCs.

The LTSES is also a basic document for the proposal of common facilities and measures (roads to make land and buildings accessible, anti-erosion measures and related structures, measures for the protection of the environment, especially to create ES and conditions for biodiversity of the landscape (bio-corridors, bio-centres, interactive elements, accompanying vegetation) water management measures and others ( $\$ 12$ Art. 4 of the Act on LCs).

The inclusion of the TSES concept into LCs enables the real implementation of TSES in agricultural land. Planting the proposed TSES elements - bio-centres, bio-corridors and interactive elements with different NFWV character - is also, albeit sporadically, performed within the process of LCs.

A proposal of new NFWV is based, on one hand, on the abiotic aspects (e.g. slope inclination, skeletality and waterlogging) and socioeconomic demands (e.g. isolation of a plant, dust and noise control, aesthetic aspects etc.) but, on the other hand, also on inadequate representation of biota in the landscape and a need to establish and interconnect present TSES elements. The Ordinance of the Geodesy, Cartography and Cadastre Authority of the Slovak Republic 79/1996 Coll., implementing the Act 162/1995 Coll. on the Real Estate Cadastre and Entering of Ownership and Other Rights to Real Estates (the Cadastral Act), defines NFWV as specialpurpose agricultural vegetation or anti-erosion protective strips (as a part of agricultural land) or ecological greenery in case of non-agricultural and non-forest land (Hrnčiarová, 2003).

With respect to practice, it is important to ensure that the designated TSES elements are integrated into the system of protected areas (existing or new) as TSES elements may not always be under legislative protection. This is significant especially from the perspective of strengthening their functionality and merits as elements of the TSES skeleton. The process of the integration of new elements of the TSES skeleton into the network of protected areas is stipulated by the Act on Nature and Landscape Protection (Act 543/2002 Coll.). The Act specifies that a TSES element can be designated as a protected landscape element if it functions as a bio-corridor, bio-centre or interactive element of local or regional importance. Further details regarding the TSES are provided in the implementing rules (e.g. Decree of MoE SR 24/2003 Coll. as amended).

To ensure spatial stabilisation of a territory, TSES includes proposals of eco-stabilising measures. Their importance increases for the purposes of agricultural land. Eco-stabilising measures should, in particular, address the functionality and whole-territory aspect of TSES. They build upon abiocomplexes (ABC) analyses, and, apart from the proposal of ecologically optimal organisation and use of the landscape, it is intended to propose subsequent agrotechnical, agrochemical and agromeliorative measures. The Slovak works authored by Miklós (1989), Húsenicová and Ružičková (1992), Izakovičová and Barančok (1996), Miklós (1996), Izakovičová (1997), Izakovičová (2000), Špulerová et al. (2013) and others also draw on the mentioned principles.

In view of the foregoing, the aim and result of the TSES is, in particular, proposal of TSES elements (bio-centres, bio-corridors and interactive elements) at different hierarchical levels. Thus, the prime objective of the TSES is to promote and preserve biodiversity of territory. In addition, the outputs are also proposals to ensure legislative protection of the TSES 
elements and the proposals of the framework concept of eco-stabilising measures besides the TSES elements (to ensure landscape stabilisation across the whole territory). The principal objectives of TSES are to maintain the network of ecologically significant landscape segments, not only because of its internal ecological value but also its favourable eco-stabilising effect on the (also ecologically disturbed) adjacent landscape and the protection of such landscape segments - which, based on the standard criteria, are not currently classed in a protective category - although, with respect to the ES of a given territory, their conservation is considered necessary. The TSES plan can be considered the most notable and most visible success of incorporating the landscape-ecological principles into the legislation of crucial planning processes (Miklós et al., 2011). Since its establishment, the TSES has been considered a part of the comprehensive concept of LANDEP landscape-ecological planning (Ružička, Miklós, 1982; Miklós, 1996). An important output of the LTSES is ensuring ecologically optimal land use and providing of whole-territory stabilisation of the landscape. This is due to the fact that TSES follows the LANDEP methodology.

Spatial planning processes are a tool to ensure an ecologically optimal spatial arrangement and functional land use (harmonisation of spatial demands, agricultural and other human activities with the landscape-ecological conditions of a territory, its potential resulting from the landscape structure as a geosystem). The outcome of correctly applied, ecologically optimal spatial arrangement and land use is not only resolution of existing landscape-ecological problems but also prevention of new ones by means of spatial-organisational protection of the landscape, which in an integrated manner ensures the favourable ecological quality of the territory (maintaining ecological functionality, balance, carrying capacity, landscape stability, landscape and biological diversity), especially by securing sufficient areas and spatial structure of ecologically stable landscape elements (forests, greenery, grasslands, wetlands, water areas, i.e. TSES) (Miklós et al., 2011). Currently, the TSES is integrated into binding regulations on landscape planning. It is a mandatory part of LC projects. It has to be taken into account also in water plans, flood protection and the documentation in environmental impact assessments of activities. In Slovakia, the TSES becomes real mainly through the LCs. LCs allows application of a broad spectrum of means and measures aimed at transformation of rural areas (economic, ecological, cultural and social) and are the sole means of restructuring of ownership and land-use rights. A particular focus is on ensuring an adequate level of technical infrastructure. The TSES covers the ecological and environmental aspects of LCs. TSES proposals are focused on optimal land use, on strengthening protection and ES of the landscape and on extension of the TSES skeleton elements.

The problem of TSES for LCs is being addressed by many authors, for example, Dumbrovský and Kolářová (1995), Izakovičová et al. (2000), Zelinka (2001), Ružičková (2006), Muchová et al. (2013), Kocián (2013), Belaňová and Diviaková (2015), Doubrava and Martének (2015) and Julény et al. (2017).

Framework guidelines for creation of LTSES for LCs are methodical instructions for LCs design (MoA SR, 2004) and methodological standards for LCs design (Muchová et al., 2009). By implementation of LTSES proposals to LCs is possible to increase the diversity of the landscape, also improving its ecostabilisation, retention and anti-erosion functions. The realisation of LTSES has a multifunctional and undoubtedly a community importance. 


\section{Material and methods}

The methodical part of the LTSES project for the studied territory is based on the methodological guidelines for the TSES (Izakovičová et al., 2000), the methodological guidelines for LCs (MoA SR, 2004) and the relevant legislation currently in force, as well as the findings and experience of the authors of the project. It was produced on a scale of 1:5,000.

The process consisted of the following steps:

Step 1: obtaining and homogenisation of the available documents (analyses of the primary landscape structure (PLS), current landscape structure (CLS)) biotic elements (current fauna and flora, tertiary landscape structure (TLS)) and the following socio-economic phenomena (SEP):

- $\quad$ information on geo-relief was obtained by means of visual interpretation of a terrain contour field generated from a digital model of geo-relief (DMR);

- the geological-substrate complex was determined from the geological map of the Podunajská nížina lowland (Pristaš, 2000);

- $\quad$ data on potential natural vegetation was taken from the original field map at 1:50,000 (Michalko et al., 1986);

- $\quad$ ecologically significant segments of the landscape were identified based on the Regional Territorial System of Ecological Stability (RTSES) for the district of Galanta (SEA, 1994);

- $\quad$ a preliminary CLS map was produced from basic topographic maps and orthophoto maps.

Step 2: verification, review and supplementation based on proprietary field surveys with detailed mapping:

- integral collection of data (Minár, 1998) emphasising mapping of soil conditions by means of shallow probing (Dutch type hand drill to a depth of $1.2 \mathrm{~m}$ conducted with 36 bores at excavated sites) - determining the soil subtype, depth and skeletality of soil, effects of ground water, soil texture by finger test; examined properties were recorded in field inventory sheet;

- $\quad$ mapping and identification of CLS elements such as land-use elements, actual biota;

- a special botanical and dendrological survey was carried out in order to map the habitats, in particular forest and shrub habitats as well as habitats of flowing and stagnant water and habitats of ruderal and weed communities. The survey was performed to analyse qualitative and quantitative characteristics of individual habitats (species composition, distribution of individual plant taxons and communities, height, width, age, health, etc.), the zoological survey aimed to map selected groups of vertebrates; ecologically significant landscape segments were identified;

- $\quad$ mapping and identification of TLS elements - socio-economical phenomena.

Step 3: synthesis of the information inputs (syntheses):

- information was reviewed and edited in accordance with the field survey and values thus obtained were later inserted into the boundaries of demarcated morphographic-genetic-positional types of geo-relief. The method of gradual superposition of analytical materials was used in parallel with the method of leading element (georelief), as well as the method of analogy and method of analysing of basic relationships between elements of the geocomplex; utilising the aforementioned means a map of abiotic complexes (ABC) was produced;

- $\quad$ geo-ecological types were obtained by adding the information on potential natural vegetation.

Step 4: interpretations and evaluation of the collected data (classification, assessment):

- the geo-ecological types were interpreted into representative potential geo-ecosystems (REPGES) (Miklós, Hrnčiarová, 2002);

- $\quad$ based on the characteristics of $\mathrm{ABC}$, relevant potential threats were evaluated: wind erosion (as proposed in Minár, Tremboš, 1994), waterlogging (as proposed in Miklós et al., 1986) as an indication of potential groundwater contamination from agricultural chemicals; the identified threats acted as constraints (limits) on the development of considered activities and the proposal of eco-stabilising measures;

- $\quad$ other selected abiotic properties were interpreted: soil tropism and soil cultivability (machinability);

- a method of two-stage spatial synthesis (Ružička, Hrnčiarová, 1995) was used to determine partial classification of the territory: classification based on abiotic factors, classification based on the CLP elements, classification based on stress factors and overall spatial classification of the territory. The territory was divided into categories as proposed by Löw et al. (1995) and Hrnčiarová and Ružička (1997), which reflect the ES of the territory; SEP were, in terms of the TSES methodology, interpreted in two ways:

- $\quad$ spatial synthesis of 'positive' elements ('threatened' SEP) was conducted by means of superposition of a CLS map and a map of classification of the territory based on the elements of CLS;

- $\quad$ spatial synthesis of 'negative' elements ('threatening' SEP) was conducted by means of superposition of a CLS map and a map of classification of the territory based on the ABC elements. 
Step 5: development of proposals for TSES:

- $\quad$ including the proposals of TSES elements (bio-centres and bio-corridors) and protected areas and the design of eco-stabilising measures;

- $\quad$ selection of real habitats to be integrated into the network of bio-centres as well as the proposals and reevaluations of protected areas was based on REGPES; the selection process was performed by confrontation of species composition of actual habitats and REPGES;

- $\quad$ the proposal of ecologically optimal use of the territory resulted from a comparison of demands of individual activities with respect to landscape properties, and the so-called complex abiotic limitation was used to gauge the suitability of the landscape and its properties for a specific anthropogenic activity.

\section{Basic characteristics of the model territory}

The model territory (Fig. 1) is situated in the cadastral territory of Hody extending over 5,385 $\mathrm{km}^{2}$, and it is a part of the town of Galanta. The territory lies in the Podunajská nížina lowland, subunit Podunajská rovina plain (Mazúr, Lukniš, 1986).

The geo-relief is of erosion-denudation character; it is a monotonous landscape formed by aggradation plains and floodplains (Miklós, Hrnčiarová, 2002). The territory can be characterised as a flat or slightly undulating floodplain. It features more noticeable elongated depressions, which are the remnants of oxbow lakes in the final stages of their existence. Elevation forms are represented by sand dunes and mounds. Depressions and convexity of the geo-relief forms is manifested in seasonal waterlogging and draught. Geo-relief inclination ranges in the intervals from 0.5 to $1^{\circ}$ and from $1^{\circ}$ to 3 . As for geometric geo-relief, forms are defined by a combination of normal and horizontal curvature of geo-relief, linear flat shapes prevail. The altitude of the area is from 116 up to $122.75 \mathrm{~m}$ above sea level. The territory is built by the geological units of the Quaternary (Holocene and recent) period, particularly by sediments of fluvial, aeolian, organogenic and anthropogenic genesis of various lithological types (Pristaš, 2000). Fluvial sediments are represented by carboniferous, clay and sandy-loam lithotype. Carboniferous sand drifts of aeolian origin form slight mounds - sand dunes. Organogenic loamy-sludgy, heavily humic sediments deposit on the bottoms of oxbow lakes. Anthropogenic sediments are represented by the material of the railway embankment.

In terms of climate, the territory is not very extensive and thus it does not exhibit more considerable climatic differences. It is in a warm climatic area with a dry or moderately dry lowland climate with mild temperature inversion. The river Šárd runs through the territory. It is covered by soil subtypes typical for large fluvial floodplains - calcaric molic fluvisols, molic gleysols and locally occurring calcaric molic chernozems. Permanently flooded areas are

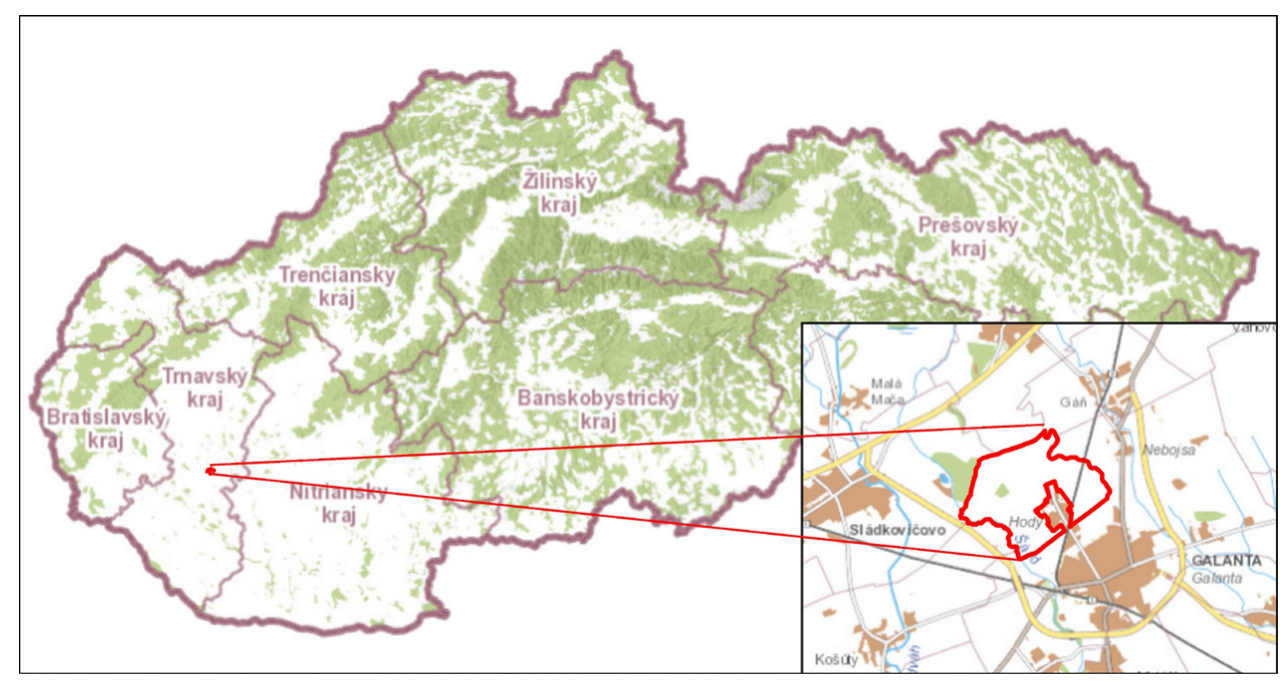

Fig. 1. Cadastral territory Hody in wider relations. 
associated with euric to gleyic fluvisols. Heavily humic loamy-sludgy sediments of organogenic character, which fill the bed of oxbow lakes, gave rise to forming organosols (stagnosols). Many original soil subtypes transformed into regosols formed on drifted sand. The embankment is covered by anthropogenic soil - anthrosols and technosols. The aforementioned soil groups (texture) fall predominantly into clay-loam to silty-claim-loam soil texture categories, sandy-loamy and loamy soils are represented less.

Potential natural vegetation is in the mapped territory represented by the following types of communities: willow-poplar floodplain forests (Salicion albae, S. triandrae), lowland floodplain forests (Ulmenion), Pannonic oak-hornbeam forests (Querco robori-Carpinenion betuli), Pontic-Pannonian xerothermophyllic oak forests (AceriQuercion) and locally would grow alderfen forests (Alnetea gutinosae). With respect to the phytogeographical-vegetation division, the territory falls into the oak zone, lowland subzone, flatland, non-wetland district and floodplain subdistrict. From the zoogeographical point of view, it is a part of terrestrial (province of steppes) as well as limnetic bio-cycle (Pont-Caspian province, county Danubian district, part of Western Slovakia) (Miklós, Hrnčiarová, 2002).

The studied territory has the character of an open agricultural area with predominantly large-block and smallblock arable land and also forest communities of hardwood alluvial forests. Almost each dirt road and watercourse is flanked by continuous or discontinuous linear vegetation. As for transport elements, unpaved roads, which prevail, crisscross the whole area. There are also a few isolated buildings: water station, apiary and barn. A bio-corridor of supra-regional significance, the Śárd, runs through the territory and Vincov les bio-centre partly extends into the area, too.

\section{Results}

Twenty-five types of ABC (Fig. 2) were designated in the studied territory. The code of an $\mathrm{ABC}$ type had the following form: X1 X2 X3 X4 X5, where X1 is the morphographic

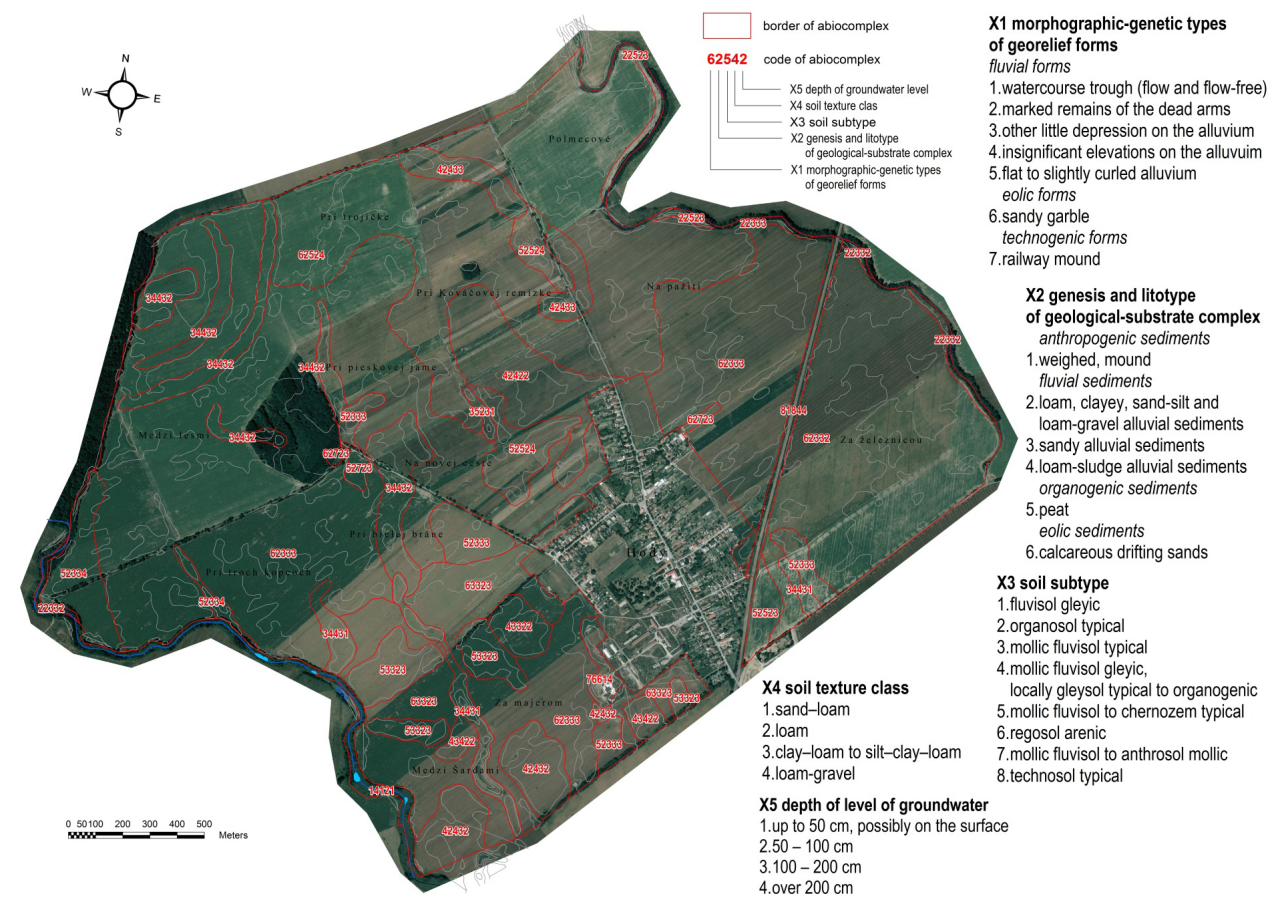

Fig. 2. Types of $A B C$ in the cadastral territory Hody. 
genetic type of a geo-relief form, $\mathrm{X} 2$ is the genesis and lithotype of geological-substrate complex, $\mathrm{X} 3$ is the soil subtype, $\mathrm{X} 4$ is the soil texture, $\mathrm{X} 5$ is the depth of the ground water level.

Geo-ecological types ware interpreted to 20 REPGES types. These geosystems are considered worthy and require conservation in a particular landscape and the hierarchical level (Miklós, Hrnčiarová, 2002).

The current landscape structure comprises of 22 types of elements, which were logically classified into 9 categories: forest vegetation, non-forest woody vegetation (NFWV), arable land, permanent cultures, watercourses and water areas, energoducts and pipelines, transport elements, agricultural elements, other areas, isolated buildings.

The territory had precisely delineated forest, shrub and water habitats, habitats of flowing water, habitats of weed and ruderal communities with the presence of plant and animal species, including protected and endangered species, for example, the snowdrop (Galanthus nivalis).

The following elements were identified as a part of spatial synthesis of threatened (positive) SEP (Fig. 3): forest stands such as commercial forests, protective forests and special purpose forests; line NFWV continuous and discontinuous such as riparian stands, alleys along dirt roads and vegetation of field baulks; groups of NFWV such as groves, small-block arable land, natural water courses and areas.

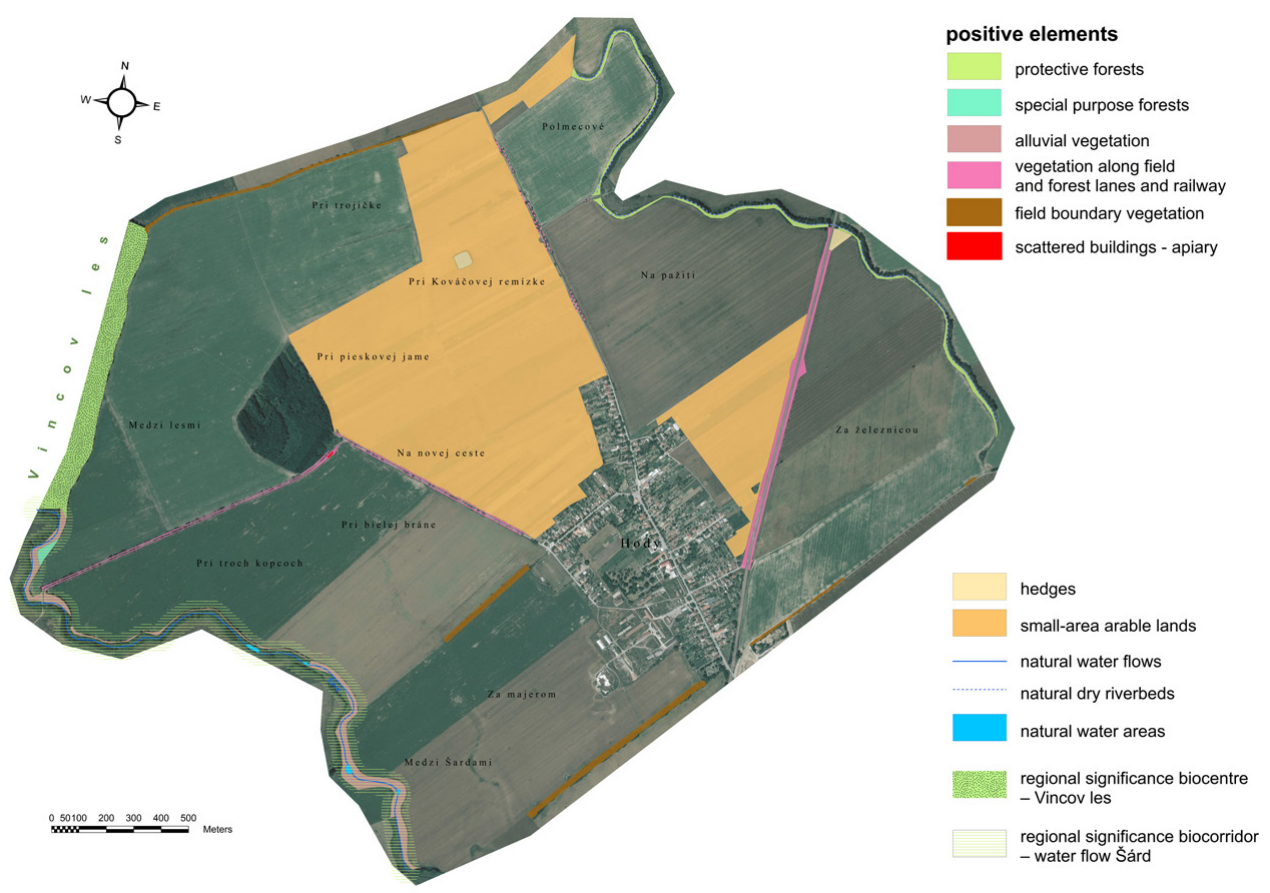

Fig. 3. Spatial synthesis of threatened phenomena in the cadastral territory of Hody. 
A regional hydric bio-corridor - the Šárd water course with more or less continuous riparian vegetation runs through the territory. No other legislative or otherwise determined elements are present in the territory. The elements for the proposals of the TSES skeleton were chosen from the 'positive' phenomena.

The selected abiotic interpretations were assessed in the studied territory such as potential vulnerability of the area to wind erosion (also accumulation) and potential groundwater contamination from agrochemicals (by the interpretation of waterlogging). The identified threats entered the evaluation as negative phenomena and were utilised in the proposals of eco-stabilising measures. Other interpreted properties were evaluated - soil tropism and soil cultivability (machinability). These properties were utilised in creating of the proposals of optimal land use where they functioned as constraints (limits) on the development of activities considered.

The following elements were identified within analyses of threatening (stressing, negative) SEP: clearcut, large-block arable lands, power lines, irrigation systems, transport elements - unpaved dirt roads, rail embankment, field dunghills, landfills, waste, isolated buildings outside residential areas - barn, waterworks, apiary, but also the residential area of the village of Hody.

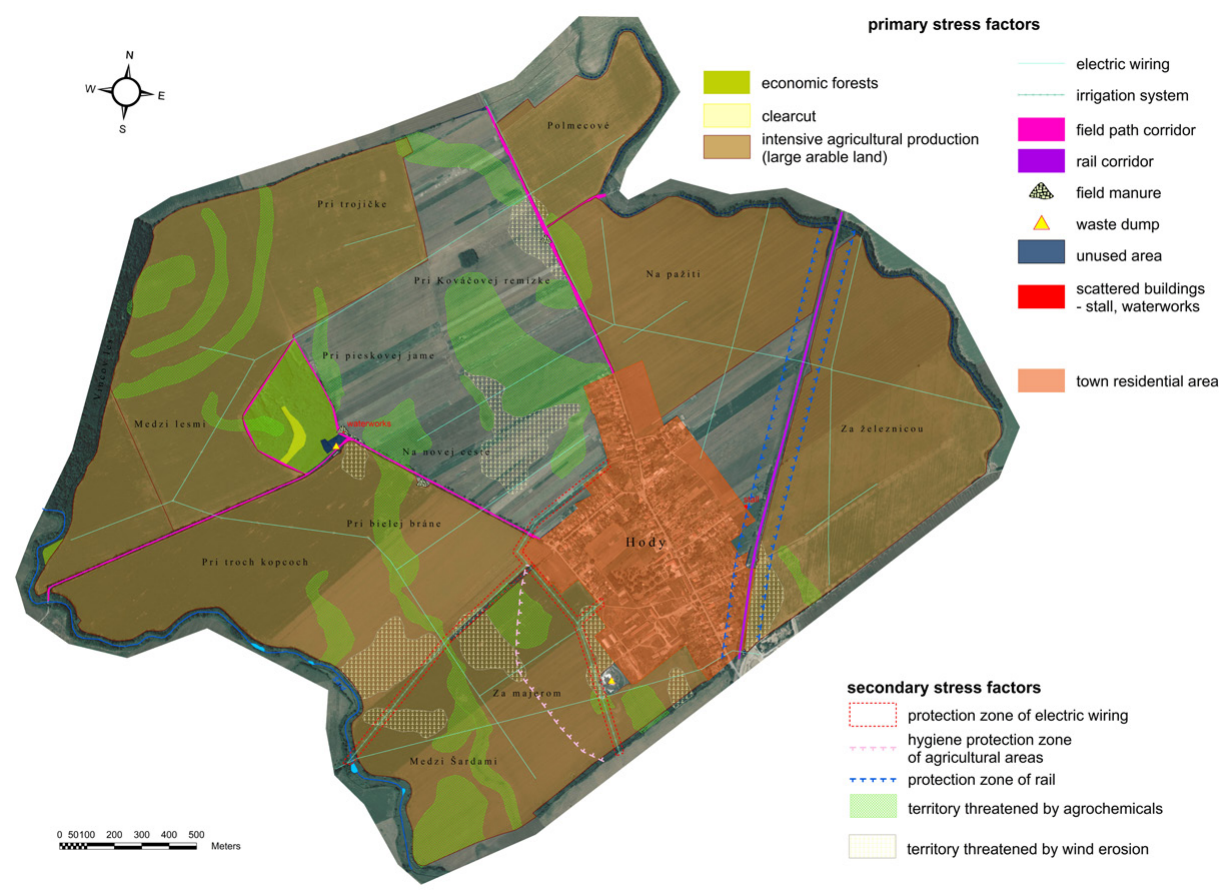

Fig. 4. Spatial synthesis of threatening phenomena in the cadastral territory of Hody. 
A separate group of intangible stressors consisted of protection zones (PZ) of technical buildings: $\mathrm{PZ}$ of agricultural grounds $(300-500 \mathrm{~m})$ to ensure protection against dust, odours and noise; PZ of railway tracks (60 $\mathrm{m}$ from the track centre on both sides); PZ of power lines (15 for low voltage power lines). On the basis of the mentioned combination of the stress factors, the Territorial System of Stress Factors (TSSF) was developed and the following types of areas with different combinations of stress factors were proposed: area with multifunctional and monofunctional effect of stress factors and areas with two-pair or three-pair dominating stress factors (Fig. 4).

The outcome of a synthesis of partial classifications was an overall classification of the territory (Fig. 5), which resulted in delineation of individual types of areas with threatened ES: areas with very high ES, high ES, average ES, low ES and very low ES.

The proposals (Fig. 6) aimed to produce a functional TSES in the studied territory. The proposals consisted of the proposal of the TSES skeleton (including re-evaluation of nature and landscape conservation) and the proposal of eco-stabilising measures (including the elimination of stress factors).

The proposals of the TSES skeleton in the studied territory included establishing 11 biocorridors of local significance, of which 7 were currently present in the territory, 4 bio-cor-

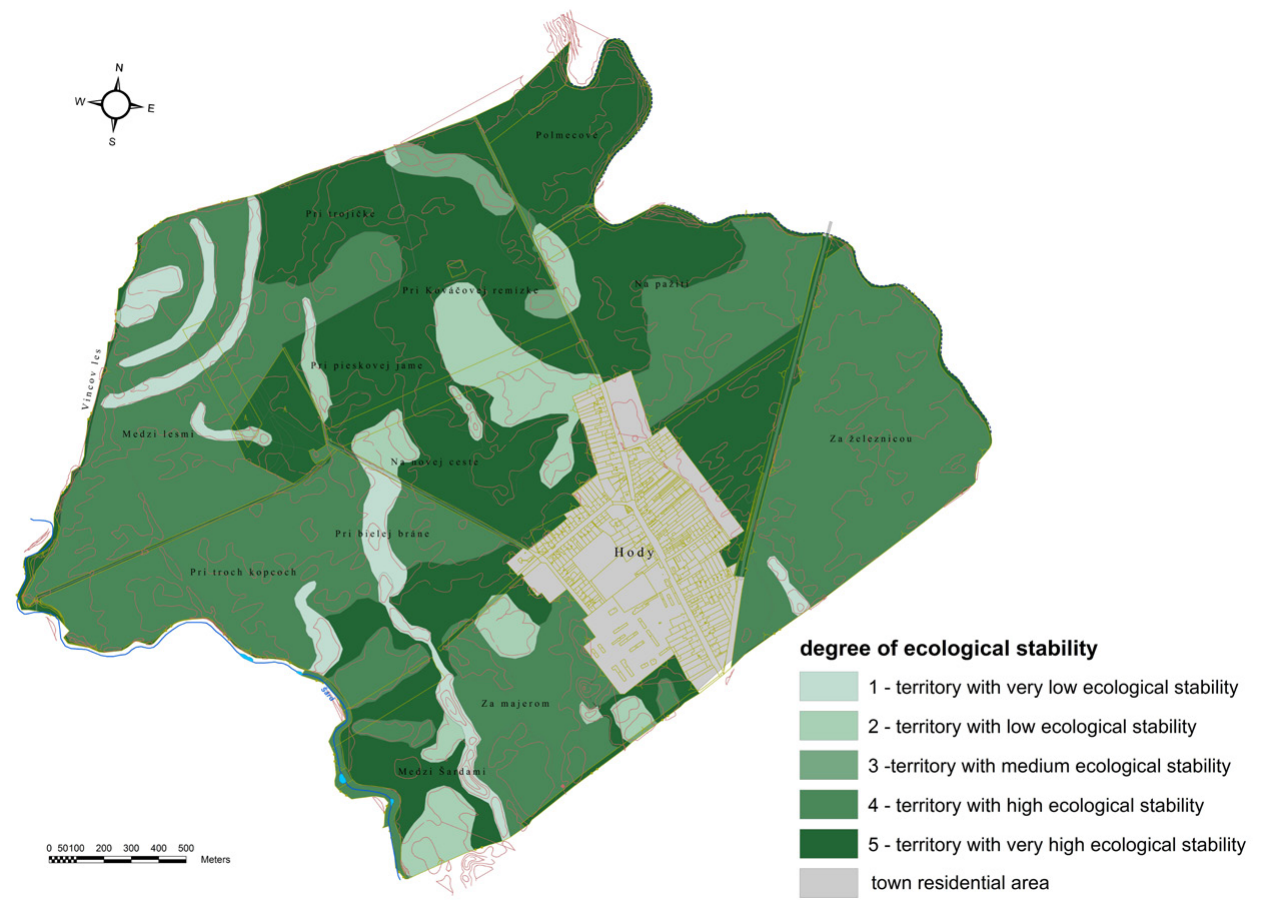

Fig. 5. Classification of the territory based on the ecological stability of the cadastral territory of Hody. 


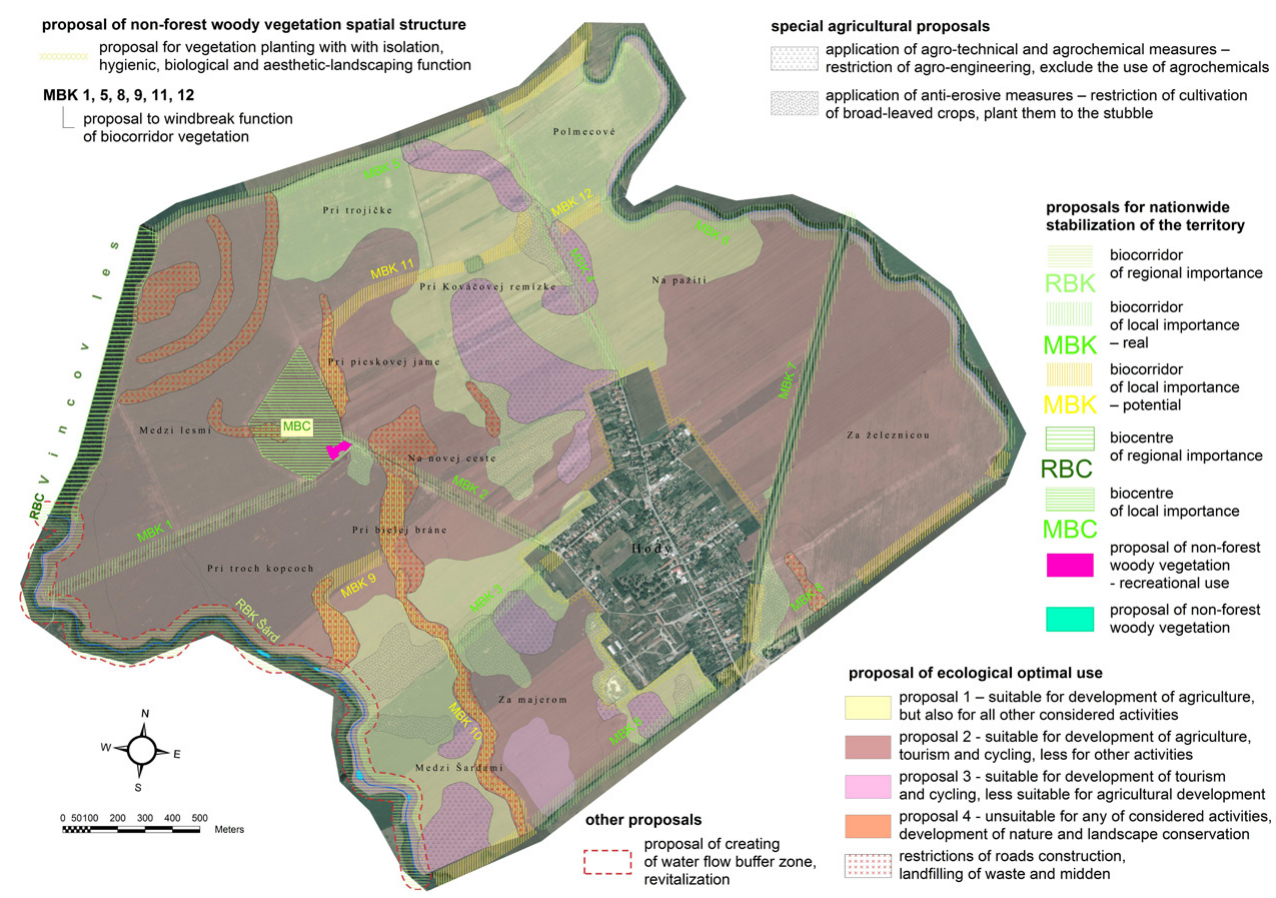

Fig. 6. LTSES proposals.

ridors were proposed to be established and 1 bio-centre of local importance. The proposed TSES elements at local level were functionally and logically interlinked with the ecological networks of higher hierarchical levels.

The proposals for eco-stabilising measures consisted of the following partial proposals:

- $\quad$ proposal for establishing new eco-stabilising elements - groups and strips of NFWV;

- proposal for ecologically optimal land use;

- $\quad$ proposal for eco-stabilising measures in forest ecosystems;

- proposal for hydro-ecological measures.

The objective of the proposal of new NFWV was to safeguard a new ecologically optimal spatial organisation of land and secure several significant ecological and environmental functions in the territory. On the basis of the aforementioned, the following measures were proposed: planting of vegetation around the residential area and landfills, which would primarily fulfil hygienic, biological and aesthetic functions. Furthermore, planting of minimum three-row, semipermeable, aerodynamically homogeneous strips of trees windbreaks were recommended. These should ensure protection against wind and also other ecological functions even without bio-corridors. The proposal also recommended suitable tree species for the territory. 
Four types of proposals were formulated within the framework of the proposals of the optimal spatial structure and land use:

- proposal 1 - suitable for agricultural development (arable land, permanent crops, farms, field dunghills) and for all other planned activities;

- $\quad$ proposal 2 - suitable for agricultural development (arable land, permanent crops, farms) and hiking and cycle tourism, less suitable for other activities;

- proposal 3 - suitable for development of hiking and cycle tourism, less suitable for agricultural development;

- $\quad$ proposal 4 - unsuitable for any of planned activities, proposal of development of nature and landscape conservation.

Several regulations were proposed for the forest ecosystems, which need to be taken into account in Forest Management Programme (FMP) (currently Forest Care Programme). The regulations were aimed at the protection of forest stands and land as well as strengthening the biodiversity of the forest ecosystems. The hydro-ecological measures focused on the protection of water resources and aquatic ecosystems.

\section{Discussion and conclusion}

In Slovakia, the TSES has a firm position in the modern plan for nature protection, spatial planning processes and environmental legislation, and its importance increases with the current Slovak and EU policies in the field of biodiversity protection (EC, 2011; MoE SR, 2013). The TSES represents one of the most advanced policies, which secures whole-territory nature conservation, biodiversity and stabilisation of unprotected and intensively used land.

The prime objective of the TSES is, amongst other things, to propose establishing the missing TSES elements (e.g. suitable vegetation on arable land and devastated areas).

The content of the TSES draws on the legislation on nature and landscape protection. The concept of the TSES was incorporated into the legislation of the protection of nature and landscape in 1994 (Act 287/1994 Coll. on Nature and Landscape Protection). However, it became a mandatory part of LCs even earlier, in 1993. The legislative basis and principles are provided by Act 330/1991 Coll. (Act on LCs). The content of the LTSES for LCs also principally stems from nature and landscape conservation legislation and was modified for the purposes of LC planning.

The TSES represents a real tool for implementation of landscape changes in order to strengthen the ES and biodiversity of the landscape. It creates conditions to approximate the situation that was successfully created in the Czech Republic. This would be only natural, as our concept of TSES as well as our relevant legislation is based on common Czech-Slovak foundations.

Several projects of LTSES have been solved in Slovakia. Some have become part of the documentation of LCs, for example, in cadastral areas of Vieska nad Žitavou (Mederly et al., 2006), Plavecký Peter (Ružičková et al., 2006), Nováky (Slobodník et al., 2006), Malé Vozokany (Mederly et al., 2007), Lužianky (Muchová, Petrovič, 2007), Tuchyňa (Ružičková et al., 2007), Pravenec (Slámková et al., 2007), Ladice (Mederly et al., 2008), Klasov (Moyzeová et al., 2008), Kanianka (Muchová et al., 2008), Horná Ves (Mederly et al., 2009), Hlboké (Me- 
derly et al., 2010), Kocurany (Diviaková et al., 2012) and Ipel'ské Úlany (Králik et al., 2015). Several projects of the TSES for the LCs were also scientifically published. Few examples are listed as follows:

- Ružičková et al. (2010) have dealt with the fragmentation of natural habitats and with the importance of restoring ecological networks. Through the LTSES designed in LCs, authors compared two geographically distant cadastral areas (Tuchyňa in Western Slovakia, Štôla in Eastern Slovakia).

- Muchová and Petrovič (2010) researched the development of the landscape structure in three time periods on three cadastral areas (Hájské, Vel'ké Vozokany and Kanianka). Authors pointed to positive changes in the landscape because of the integration of TSES proposals into LCs. Through the LCs, new landscape elements to increase the diversity and stability of the landscape have been created.

- Moyzeová and Kenderessy (2015) solved the creation of an ecological network in cadastral area Klasov. Authors have dealt with the revitalisation of existing and with creation of new fragments of natural habitats. They also solved the system of eco-stabilisation measures and management.

- Muchová et al. (2016) pointed out the problems that currently restrict rural development on the territory of the Žitava basin. Authors pointed to the low ES of the landscape, frequent flooding, increasing soil erosion and so on. They highlighted the main problems in water management and environmental protection.

- Belaňová and Diviaková (2017) presented a proposal of TSES skeleton and anti-erosion measures into proposal of GPFAT. The model territory was cadastral area Kocurany. Authors pointed to insufficient acceptance of the TSES proposals in the LCs. Nonetheless, they considered LCs as a suitable tool to create appropriate conditions for the practical implementation of the TSES.

This article describes an LTSES, which was also developed within the LC project in the cadastral territory of Hody (Galanta). The outputs of the evaluation are the proposals aimed to produce a functional TSES in the studied territory. The proposals consisted of the proposal of the TSES skeleton (including re-evaluation of nature and landscape conservation) and the proposal of eco-stabilising measures (including the elimination of stress factors). The proposed TSES elements at local level were functionally and logically interlinked with the ecological networks of higher hierarchical levels. The proposals for eco-stabilising measures consisted partial proposals - proposal for establishing new eco-stabilising elements - groups and strips of NFWV, proposal for ecologically optimal land use, proposal for eco-stabilising measures in forest ecosystems and proposal for hydro-ecological measures. In the model area, it is possible in certain places to consider all agricultural and also all other activities. In some places, all agricultural activities were appropriate, non-agricultural, tourism and agrotourism were only suitable. In certain places, non-agricultural use is optimal, mainly hiking and cycling. Some locations where nature and landscape protection is optimal are not suitable for any economic use. Different intensity of use is caused by limiting factors that result from the properties of the primary, secondary and tertiary landscape structure. The main objective was to develop a functional TSES. Outputs constitute basis for the GPFAT in the LCs and for the proposal of common facilities and measures in the model territory. Project 
of LTSES was a key aspect of the 'greening' of the agricultural landscape. Without accepting and implementing LTSES proposals into the LCs, it would not be possible to ensure the integrated protection and the creation of an agricultural landscape.

\section{Acknowledgements}

This paper was supported by the VEGA scientific grant agency, project no. 1/0096/16, and the KEGA cultural and educational grant agency, project no. 13TUZ-4/2016.

\section{References}

Act 50/1976 Coll. on Territorial Planning and Building Code (Building Act) as amended.

Act 330/1991 Coll. on Ground Arrangements, Land Ownership, Land Offices, Land Fund and Land Associations (Act on LCs) as amended.

Act 287/1994 Coll. on Nature and Landscape Protection as amended.

Act 162/1995 Coll. on the Real Estate Cadastre and Entering of Ownership and Other Rights to Real Estates (the Cadastral Act) as amended.

Act 237/2000 Coll on Territorial Planning and Building Code (Building Act) as amended.

Act 543/2002 Coll. on Nature and Landscape Protection as amended.

Agger, P. \& Brandt J. (1988). Dynamics of small biotopes in Danish agricultural landscapes. Landsc. Ecol., 1, $227-240$. DOI: $10.1007 / \mathrm{BF} 00157695$

Bastian, O. \& Schreiber K.F. (Eds.) (1994). Analyse und ökologische bewertung der landschaft. Stuttgart: Fischer Verlag Jena.

Belaňová, E. \& Diviaková A. (2015). Uplatnenie miestnych územných systémov ekologickej stability krajiny v projektovaní pozemkových úprav. Acta Facultatis Ecologiae, 32(1), 5-12.

Belaňová, E. \& Diviaková A. (2017). Vybrané aspekty projektovania pozemkových úprav v obci Kocurany. In L. Miklós \& A. Diviaková (Eds.), Ciele trvalo udržatelného rozvoja: méta integrovaného manažmentu životného prostredia (pp. 105-124). Zborník pôvodných vedeckých prác. Zvolen.

Bennett, G. (1998). Guidelines for establishing the Pan-European ecological network. Strasbourg: Council of Europe.

Bennett, G. \& Mulongoy K.J. (2006). Review of experience with ecological networks, corridors and buffer zones. Montreal: Secretariat of the Convention on Biological Diversity.

Boitani, L., Falcucci, A., Maiorano, L. \& Rondinini C. (2007). Ecological networks as conceptual frameworks or operational tools in conservation. Conserv. Biol., 21(6), 1414-1422. DOI: 10.1111/j.1523-1739.2007.00828.x

Bonnin, M. (2007). The Pan-European Ecological Network-taking Stock. Nature and Environment, No. 146. Council of Europe Publishing.

Bouwma, I.M. \& Jongman R.H.G. (1998). From national to European ecological networks. In B.C.W. Delbaere (Ed.), Facts and figures on Europe's biodiversity - State and trends 1998-1999 (pp. 51-53). Tilburg: European Centre for Nature Conservation.

Brandt, J. (1985). Small biotope structures as a synthesizing feature in agricultural landscapes. Proc. I.G.U. Dessau, $52-61$.

Brandt, J. (1995). Ecological networks in Danish planning. Landschap, 12(3), 63-76.

Buček, A. \& Lacina J. (1979). Biogeografická diferenciace krajiny jako jeden z ekologických podkladů pro územní plánování. Územní Plánování a Urbanismus, 6, 382-387.

Buček, A., Lacina, J. \& Löw J. (1986). Územní systémy ekologické stability krajiny. Životné Prostredie, 20(2), 82-86.

Buček, A. \& Lacina J. (1993). Územní systémy ekologické stability. Veronica, 8(1), 48.

Buček, A., Lacina, J. \& Míchal I. (1996). An ecological network in the Czech Republic. Veronica (Special 11th issue).

Buček, A. (2013). Ecological network as natural infrastructure in the cultural landscape (in Czech). Životné Prostredie, $47(2), 82-85$.

Bunce, R.G.H., Watkins, J.W., Brignall, P. \& Orr J. (1996). A comparison of the environmental variability within the European Union. In R.H.G. Jongman (Ed.), Ecological and landscape consequences of land use change in Europe. Tilburg: European Centre for Nature Conservation, Publication Series on Man and Nature, 2.

CE, 2000. European landscape convention. Florence. 
Cook, E.A. \& van Lier H.N. (Eds.) (1994). Landscape planning and ecological networks. Lausanne-New York-OxfordShannon-Tokyo: Elsevier.

Decree of the MoE SR 24/2003 Coll., implementing Act 543/2002 Coll. on Nature and Landscape Protection as amended.

Diviaková, A., Kočický, D., Novikmec, M. \& Svitok M. (2012). Miestny územný systém ekologickej stability pre projekt pozemkových úprav k.ú. Kocurany (okres Prievidza). Zvolen: TU Zvolen.

Doubrava, D. \& Martének J. (2015). Vymezení ÚSES v návrzích komplexních pozemkových úprav, co konktétně to znamená? In Sborník ze semináře ÚSES - zelená páteř krajiny a Ekologické síte v krajinè (pp. 120-127). Brno.

Drdoš, J., Miklós, L., Kozová, M. \& Urbánek J. (1995). Základy krajinného plánovania. Zvolen: TU Zvolen.

Dumbrovský, M. \& Kolářová D. (1995). Zásady navrhování územních systémů ekologické stability v rámci procesu komplexních pozemkových úprav. Praha-Zbraslav: VÚMaOP.

EC (2011). Naše životné poistenie, náš prírodný kapitál: stratégia EÚ v oblasti biodiverzity do roku 2020. Oznámenie Komisie Európskemu parlamentu, Rade, Európskemu hospodárskemu a sociálnemu výboru a Výboru regiónov COM (2011) 244, 8 September 2011. Brussels.

ECNC (1996). Pan-European biological and landscape diversity strategy. Nature and Environment, No. 74, Tilburg: Council of Europe Press.

Forman, R.T.T. (1983). Corridors in a landscape: their ecological structure and function. Ekológia (ČSSR), 2, 375-387.

Forman, R.T.T. \& Baundry J. (1984). Hadgerows and hedgerow network in landscape ecology. Environm. Manag., 8, 495-510. DOI: 10.1007/BF01871575.

Hargis, CH.D. Bissonette, J.A. \& Turner D.L. (1999). The influence of forest fragmentation and landscape pattern on American martens. J. Appl. Ecol., 36, 157-172. DOI: 10.1046/j.1365-2664.1999.00377.x

Hobbs, R.J., Hussey, B.M. \& Sanders D.A. (1990). Nature conservation: the role of corridors. J. Environ. Manag., 31, 93-94. DOI: 10.1016/S0301-4797(05)80017-9

Hrnčiarová, T. \& Ružička M. (1997). Classification of the ecological stability of the territory. Ekológia (Bratislava), 16(1), 81-98.

Hrnčiarová, T., Ružička, M., Izakovičová, Z., Hrašna, M., Bedrna, Z., Drdoš, J. \& Supuka J. (2000). Metodický postup ekologicky optimálneho využívania územia v rámci prieskumov a rozborov pre územný plán obce. Bratislava: MŽP SR, Združenie KRAJINA 21.

Hrnčiarová, T. (2003). Územný systém ekologickej stability - od filozofie k realizácii. Seminár ÚSES - zelená pátěr krajiny. Sborník k semináři. 9.-10. september 2003. Brno: AOPK ČR.

Húsenicová, J. \& Ružičková J. (1992). Supra-regional territorial system of ecological stability in the Slovak Republic. In Proceedings of the field workshop ecological stability of landscape ecological infrastructure ecological management (pp. 60-65). Kostelec, Prague: Federal Committee for the Environment, Institute of Applied Ecology.

Ignatieva, M., Stewart, G.H. \& Meurk C. (2011). Planning and design of ecological networks in urban areas. Landscape and Ecological Engineering, 7(1), 17-25. DOI: 10.1007/s11355-010-0143-y.

Izakovičová, Z. \& Barančok P. (1996). Methodological principles of regional 'TSES' performance in the district of Dunajská Streda. Ekológia (Bratislava), 15(4), 449-454.

Izakovičová, Z. (1997). Evaluation of the anthropogenic change of the landscape structure. Ekológia (Bratislava), $16(1), 73-80$.

Izakovičová, Z. (2000). Evaluation of the stress factors in the landscape. Ekológia (Bratislava), 19(1), 92-103.

Izakovičová, Z., Štefunková, D. \& Ružička M. (2000a). The model of formation of the territorial system of ecological stability on the local level for land adjustment. Ekológia (Bratislava), 19(2), 268-275.

Izakovičová, Z., Hrnčiarová, T., Králik, J., Liška, M., Miklós, L., Moyzeová, M., Pauditšová, E., Ružičková, H., Šíbl, J. \& Tremboš P. (2000b). Metodické pokyny na vypracovanie projektov regionálnych územných systémov ekologickej stability a miestnych územných systémov ekologickej stability. Bratislava: MŽP SR, Združenie KRAJINA 21.

Jančura, P. (1994). Manuál k metodike ÚSES I. - V. diel. Banská Bystrica: SAŽP.

Jongman, R.H.G. (1995). Nature conservation planning in Europe: Developing ecological networks. Landsc. Urban Plann., 32, 169-183. DOI: 10.1016/0169-2046(95)00197-O

Jongman, R.H.G. \& Kristiansen I. (1998). National and regional approaches for ecological networks in Europe. Strasbourg: Council of Europe.

Jongman, R.H.G. \& Bunce R.G.H. (2000). Landscape classification, scales and biodiversity in Europe. In Ü. Mander \& R.G.H. Jongman (Eds.), Consequences of land use changes (pp. 11-38). WIT Press.

Jongman, R.H.G. \& Pungetti G. (2004). Ecological networks and greenways: concept, design, implementation. Cambridge: University Press. 
Jongman, R.H.G., Bouwma, I.M., Griffioen, A., Jones-Walters, L. \& van Doorn A.M. (2011). The Pan European Ecological Network: PEEN. Landsc. Ecol., 26(3), 311 -326. DOI: 10.1007/s10980-010-9567-x.

Julény, A., Julény, A. \& Muchová Z. (2017). Efektívne nástroje obnovy vidieckej krajiny. In L. Miklós \& A. Diviaková (Eds.), Ciele trvalo udržatelného rozvoja: méta integrovaného manažmentu životného prostredie (pp. 95-104). Zborník pôvodných vedeckých prác. Zvolen.

Jurko, A. (1986). Krajinnoekologická významnost’ rastlinných spoločenstiev. In Ekologická optimalizácia využívania Východoslovenskej nižiny III. (pp. 214-218). Bratislava: ÚEBE SAV.

Kavaliauskas, P. (1995). The nature frame (Special issue on ecological networks). Landschap, 95(3), 17-26.

Kocián, J. (2013). Řešení ÚSES v pozemkové úpravě - formalita nebo zásadní záležitost. In Sborník ze semináře ÚSES - zelená páteř krajiny a Ekologické síte v krajině (pp. 70-74). Brno.

Králik, J., Kučerová, M., Roštanská, Z., Juhásová, J. \& Veselovská B. (2015). Návrh MÚSES na účely pozemkových úprav v katastrálnom území obce Ipel’ské Ulany. Banská Bystrica: SAŽP, Bratislava: Centrum integrovanej starostlivosti o krajin.

Kubeš, J. (1996). Biocentres and corridors in a cultural landscape. A critical assessment of the 'territorial system of ecological stability'. Landsc. Urban Plann., 35(4), 231-240. DOI: 10.1016/S0169-2046(96)00321-0

Löw, J., Míchal, I., Buček, A., Lacina, J., Plos, J. \& Petříček V. (1995). Rukovět projektanta místního územního systemu ekologické stability. Doplněk. Brno.

Mackovčin, P. (2000). A multi-level ecological network in the Czech Republic: Implementing the territorial system of ecological stability. GeoJournal, 51, 211-220. DOI: 10.1023/A:1017518529210.

Mander, Ü., Palang, H. \& Jagomägi J. (1995). Ecological networks in Estonia: impact of landscape change. Landschap, 12(3), 27-38.

Mander, Ü., Jagomägi, J. \& Külvik M. (1988). Network of compensative areas as an ecological infrastructure of territories: connectivity in landscape ecology. In K.F. Schreiber (Ed.), Proceedings of the second international seminar of the International association for landscape ecology (pp. 35-38). Münster: Münstersche Geographische Arbeiten.

Mazúr, E. \& Lukniš M. (1986). Geomorfologické členenie SSR a ČSSR. Čast'Slovensko. Bratislava: Slovenská kartografia.

Mederly, P., Halada, L., Trnka, A., Krautschneider, J., Petrovič, F., Mederlyová, O., Chlpík, J., Vlcková, T. \& Pekárik J. (2006). Miestny územný system ekologickej stability územia na účely pozemkových úprav - obec Vieska nad Žitavou. Nitra: REGIOPLÁN, Žilina: EKOPED.

Mederly, P., Halada, L., Trnka, A., Krautschneider, J., Petrovič, F., Mederlyová, O., Chlpík, J., Vlcková, T. \& Pekárik J. (2007). Miestny územný system ekologickej stability územia na účely pozemkových úprav - obec Malé Vozokany. Nitra: REGIOPLÁN, Žilina: EKOPED.

Mederly, P., Halada, L., Trnka, A., Krautschneider, J., Petrovič, F., Mederlyová, O., Chlpík, J., Vlcková, T. \& Pekárik J. (2008). Miestny územný system ekologickej stability územia na účely pozemkových úprav - obec Ladice. Nitra: REGIOPLÁN, Žilina: EKOPED.

Mederly, P., Halada, L., Trnka, A., Krautschneider, J., Petrovič, F., Mederlyová, O., Chlpík, J., Vlcková, T. \& Pekárik J. (2009). Miestny územný system ekologickej stability územia na účely pozemkových úprav - obec Horná Ves. Nitra: REGIOPLÁN, Žilina: EKOPED.

Mederly, P., Halada, L., Trnka, A., Krautschneider, J., Petrovič, F., Mederlyová, O., Chlpík, J., Vlcková, T. \& Pekárik J. (2010). Miestny územný system ekologickej stability územia na účely pozemkových úprav - obec Hlboké. Nitra: REGIOPLÁN, Žilina: EKOPED.

Michalko, J., Berta, J. \& Magic D. (1986). Geobotanická mapa ČSSR. Slovenská republika. Bratislava: Veda,vydavatel'stvo SAV. Miklós, L. (1986). Stabilita krajiny v ekologickom genereli SSR. Životné Prostredie, 20(2), 87-93.

Miklós, L., Kozová, M. \& Ružička M. et al. (1986). Ekologický plán využívania Východoslovenskej nížiny v mierke 1:25 000. In Ekologická optimalizácia využívania Východoslovenskej nížiny (pp. 5-312). Bratislava: ÚEBE CBEV SAV.

Miklós, L. (1989). The general ecological model of the Slovak Socialist Republic - methodology and contents. Landsc. Ecol., 3(1), 43-51.DOI: 10.1007/BF00157755.

Miklós, L., Hrnčiarová, T., Izakovičová, Z., Moyzeová, M., Dobrovodská, M., Štefunková, D. \& Krnáčová Z. (1990). Ekologický generel ozelenenia polnohospodárskej krajiny SR. I. čast'- Krajinnoekologické podmienky. Ekologická štúdia. Bratislava: ÚKE SAV.

Miklós, L. (1996). The concept of the territorial system of ecological stability in Slovakia. In R.H.G. Jongman (Ed.), Ecological and landscape consequences of land use change in Europe (pp. 385-406). Tilburg: ECNC, Publications Series on Man and Nature 2. 
Miklós, L. \& Izakovičová Z. (1997). Krajina ako geosystém. Bratislava: Veda, vydavatel'stvo SAV.

Miklós, L. \& Hrnčiarová T. (Eds.) (2002). Atlas krajiny Slovenskej republiky. Bratislava: MŽP SR, Banská Bystrica: SAŽP.

Miklós, L. \& Izakovičová, Z. et al. (2006). Atlas reprezentatívnych geoekosystémov Slovenska. Bratislava: ÚKE SAV.

Miklós, L., Diviaková, A. \& Izakovičová Z. (2011). Ekologické siete a územné systémy ekologickej stability. Zvolen: TU Zvolen.

Minár, J. \& Tremboš P. (1994). Prírodné hazardy - hrozby, niektoré postupy ich hodnotenia. Acta Facultatis Rerum Naturalium Universitatis Comenianae, 35, 173-191.

Minár, J. (1998). Georeliéf a geoekologické mapovanie vo velkých mierkach. PRIF UK, Bratislava.

Míchal, I. (1992). Ekologická stabilita. Brno: Veronica.

MoA SR (2004). Pozemkové úpravy. Metodický návod. V̌̌eobecná čast'. Konanie o začatí pozemkových úprav a príprava realizácie spoločných zariadení a opatrení, aktualizovaná verzia. Bratislava: Ministerstvo pôdohospodárstva SR.

MoE SR (1993). Metodické pokyny na vypracovanie dokumentov územného systému ekologickej stability. Bratislava.

MoE SR (1996). AGENDA 21a ukazovatele trvalo udržatelného rozvoja. Bratislava.

MoE SR (1997). Národná stratégia ochrany biodiverzity na Slovensku. Bratislava.

MoE SR (2013). Aktualizovaná národná stratégia ochrany biodiverzity pre roky 2012 - 2020. Bratislava.

Moyzeová, M., Izakovičová, Z., Špulerová, J., Kenderessy, P. \& Lieskovský J. (2008). Miestny územný systém ekologickej stability k.ú. Klasov pre potreby pozemkových úprav. Bratislava: ÚKE SAV.

Moyzeová, M. \& Kenderessy P. (2015). Territorial systems of Ecological Stability in Land Consolidation Projects (example of proposal for the LSES of Klasov Village, Slovac Republic), Ekológia (Bratislava), 34(4), 356-370. DOI: 10.1515/eko-2015-0032.

Muchová Z. \& Petrovič F. (2007). Návrh MÚSES na účely pozemkových úprav v obvode projektu pozemkových úprav vk. ú. Lužianky. Nitra.

Muchová Z., Daniš J., Konc L. \& Šimora R. (2008). Návrh MÚSES na účely pozemkových úprav v obvode projektu pozemkových úprav v $k$. ú. Kanianka. Nitra.

Muchová, Z., Vanek, J., Halaj, P., Hrnčiarová, T., Konc, L., Raškovič, V., Stred’anská, A., Šimonides, I. \& Vašek A. (2009). Metodické štandardy projektovania pozemkových úprav. Nitra: SPU.

Muchová, Z. \& Petrovič F. (2010). Changes in the landscape due to land consolidations. Ekológia (Bratislava), 29(2), 140-157. DOI: 10.4149/ekol_2010_02_140.

Muchová, Z., Hrnčiarová, T. \& Petrovič F. (2013). Miestny územný systém ekologickej stability na účely pozemkových úprav. Nitra: SPU.

Muchová, Z., Leitmanová, M. \& Petrovič F. (2016). Possibilities of optimal land use as a consequence of lessons learned from land consolidation projects (Slovakia). Ecological Engineering, 90, 294-306. DOI: 10.1016/j.ecoleng.2016.01.018

Naveh, Z. \& Lieberman A.S. (1994). Landscape ecology: theory and application. Springer-Verlag.

Opdam, P., Steingröver, E. \& van Rooij S. (2006). Ecological networks: A spatial concept for multi-actor planning of sustainable landscapes. Landsc. Urban Plann., 75(3-4), 322-333. DOI: 10.1016/j.landurbplan.2005.02.015

Ordinance of Geodesy, Cartography and Cadastre Authority of the Slovak Republic 79/1996 Coll., implementing the Act on the real estate cadastre and entering of ownership and other rights to real estates (the Cadastral Act).

Pascual, M. \& Dunne J.A. (2006). Ecological networks: Linking structure to dynamics in food webs. Oxford: Oxford University Press.

Pristaš, J. (2000). Geologická mapa Podunajskej nižiny - Nitrianska pahorkatina. Bratislava: ŠGÚDŠ.

Renetzeder, C., Wrbka, T., Mücher, S., Eupen, M.V. \& Kiers M. (2010). Landscape structure analysis in selected European regions and its use for sustainability impact assessment. In J. Andel, I. Bicik, P. Dostal, Z. Lipsky \& S.G. Shahneshin (Eds.) Landscape modelling (236 pp.). Geographical Space, Transformation and Future Scenarios. Series: Urban and Landscape Perspectives, 8.

Ružička, M., Jurko, A., Kozova, M., Zigrai, F. \& Svetlosanov V. (1982). Evaluation methods of landscape stability on agricultural territories in Slovakia. VI ${ }^{\text {th }}$ Int. Symp. on Problems of Landscape Ecological Research. October 2530, Pieštany (ČSSR).

Ružička, M. \& Miklós L. (1982). Landscape-ecological planning (LANDEP) in the process of territorial planning. Ekológia (ČSSR), 1, 297-312.

Ružička, M. \& Hrnčiarová T. (1995). Metóda klasifikácie ekologickej stability územia. Životné Prostredie, 29(5), 249-254. 
Ružičková, J. (2006). ÚSES a projekty pozemkových úprav na Slovensku - Aktuálny stav a metodické aspekty. In Sbornik ze semináre ÚSES - zelená páter krajiny a Ekologické site v krajine (pp. 110-117). Brno.

Ružičková, J., Reháčková, T., Pauditšová, E. \& Kalivodová E. (2006). Plán miestneho územného systému ekologickej stability $k$. ú. Plavecký Peter pre projekt pozemkových úprav. Bratislava.

Ružičková, J., Kalivodová, E., Lehotská, B. \& Moravčíková Z. (2007). Plan of Local Territorial System of Ecological Stability in Cadastral Area Tuchyña for Land Consolidation Project. Bratislava: Tiliana.

Ružičková, J., Miklošovičová, A. \& Moravčíková Z. (2010). Ecological networks in Slovakia, particularities on the local level in land consolidation projects. Journal of International Scientific Publication: Ecology \& Safety, 4(2), 387-414. http://www.science-journals.eu

SCE (1992). Metodika územných systémov ekologickej stability. Bratislava: Slovenská komisia pre životné prostredie.

Schilleci, F., Todaro, V. \& Lotta F. (2017). Connected Lands: New Perspectives on Ecological Networks Planning. Springer.

SEA (1994). Regionálny územný systém ekologickej stability okresu Galanta. Trnava.

SEA (2009). Metodické pokyny na vypracovanie aktualizovaných dokumentov R-ÚSES. Bratislava: SAŽP CMŽP OMK.

Selman, P. (1993). Landscape ecology and countryside planning: Vision, theory and practice. Journal of Rural Studies, 9, 1-21. DOI: 10.1016/0743-0167(93)90002-2

Sepp, K. \& Kaasik A. (Eds.) (2002). Development of National Ecological Networks in the Baltic Countries in the framework of the Pan-European Ecological Network. Warszawa: IUCN.

Slámková, M., Lamošová, L. \& Súlovský A. (2007). Miestny územný systém ekologickej stability k. ú. Pravenec pre účely PPÚ. Banská Bystrica: SAŽP, Žilina: Centrum integrovanej starostlivosti o krajinu.

Slobodník, V., Janák, M., Ružičková, J., Straka, P. \& Lasák R. (2006). MÚSES pre potreby PPÚ v k. ú. Nováky. Bratislava: DAPHNE, Inštitút aplikovanej ekológie.

Špulerová, J., Dobrovodská, M., Izakovičová, Z., Kenderessy, P., Petrovič, F. \& Štefunková D. (2013). Developing a strategy for the protection of traditional agricultural landscapes based on a complex landscape-ecological evaluation (the case of a mountain landscape in Slovakia). Moravian Geographical Reports, 21(4), 15-26. DOI: 10.2478/mgr-2013-0017.

Tardy, J. \& Végh M. (Eds.) (2006). National Ecological Networks of European Countries $1: 4000$ 000. Tilburg: ECNC.

Wrbka, T., Stocker-Kiss, A., Schmitzberger, I. \& Peterseil J. (2005). Network Landscapes of Austria - Identification and Ecological Assessment. In É. Konkoly Gyuró (Ed.) Greenways (pp. 47-62). Conference Presentations on Ecological Corridors, Green Corridors. Sopron.

Zelinka, L. (2001). Pozemkové úpravy a ich význam pri zaistovaní stability krajiny. In V. Konrád a kol. (Eds.) Súčasný stav a perspektívy ekológie a environmentalistiky (pp. 241-244). Zborník z medzinárodnej vedeckej konferencie pri príležitosti desiateho výročia založenia FEE. Zvolen: TU. 